\title{
Views of the chairs of Scottish health boards on engagement with quality management and comparisons with English trusts
}

\author{
${ }^{1} \mathrm{E}$ Bream, ${ }^{2} \mathrm{AK}$ Jha, ${ }^{3} \mathrm{AM}$ Epstein, ${ }^{4} \mathrm{~N}$ Black \\ ${ }^{1}$ Honorary Research Fellow, Department of Health Services Research E Policy, London School of Hygiene E Tropical Medicine; ${ }^{2}$ Professor, \\ Department of Health Policy \& Management, Harvard School of Public Health; ${ }^{3}$ Professor of Health Policy E Management, Department of \\ Health Policy \& Management, Harvard School of Public Health; ${ }^{4}$ Professor of Health Services Research, Department of Health Services \\ Research $\mathcal{E}$ Policy, London School of Hygiene E Tropical Medicine, London, UK
}

\section{ABSTRACT}

Objective: To describe the views of the chairs of Scottish health boards on the engagement of their boards with healthcare quality and to compare them with the views of the chairs of boards of English acute trusts. The focus of the Scottish Health Boards is on providing and commissioning care, while in England the acute trusts only provide care.

Methods: We mailed a questionnaire, based on one used in England, to the 14 health board chairs in NHS Scotland in January 20II.The results were compared with the results of a similar questionnaire given to English acute trust chairs in 2009.

Results: Most chairs in Scotland (67\%) prioritised oversight of quality. Quality is considered at most Board meetings (92\%), taking over $20 \%$ of time for $69 \%$ of chairs. Most boards have local quality targets and feedback quality data to staff. Compared with England, boards in Scotland meet less frequently and focus less on quality (shorter discussions, less frequent data review, fewer local targets) but they are more optimistic about their board's performance.

Conclusions: Although most chairs of Scottish boards view quality as a priority, they pay less attention to it than chairs in England, possibly due to their additional role in commissioning care.

KEYWORDS Delivery of healthcare, governing board, quality of healthcare

DECLARATION OF INTERESTS Professors Jha and Epstein received funding from the Health Foundation to perform related work in England.

Correspondence to E Bream, Department of Public Health, NHS Lothian, Waverley Gate, Waterloo Place,

Edinburgh EHI 3EG, UK

tel. +44 (0) I 3 I 4655459

e-mail elizabeth.bream@nhs.net

\section{INTRODUCTION}

The drive to improve the quality and safety of healthcare has increased in Scotland in recent years, as is evident by the implementation of a national patient safety programme (the Scottish Patient Safety Programme [SPSP]) and the publication of a quality strategy (NHS Scotland Healthcare Quality Strategy) in 2010.,2 These have been accompanied by an increased emphasis on the important role of health boards in the leadership and governance of quality and performance of services. To support this, the US Institute for Healthcare Improvement, a partner of the SPSP, undertook 'Boards on board' sessions in Scotland in $20 \mathrm{II}$ and 2012, which aimed to 'fully engage the governance leadership in quality and safety. ${ }^{3}$

Boards in the NHS in the UK consist of the executive and non-executive directors responsible for the strategy, governance and performance of the healthcare body. Executive members generally include a chief executive and directors of finance, medicine and nursing. Nonexecutive members include those with experience in relevant areas such as finance and corporate management. They may also include members to represent the local population, but there is no statutory requirement for this. Boards are chaired by a non-executive who has usually previously served as a member of the same or another NHS board. Non-executive members are selected by public appointment committees though the use of elections is currently being piloted in Scotland. ${ }^{4}$

Although England provides broadly similar healthcare services to Scotland, over the past two decades there has been an increasing divergence of policy with differences in funding, structures and governance arrangements. ${ }^{5,6}$ There are two key differences: First, in Scotland there is no structural separation between commissioning (purchasing) and providing care, with 14 health boards responsible for both, whereas in England these functions have been separated between commissioners and providers since 1991; the second major difference, connected to the first, is that in England there is greater dependence on market forces between competing providers to improve the quality and productivity of services, whereas in Scotland these forces are not in action. 
It is beyond the scope of this paper to provide a detailed comparison of the population breakdown of the two countries and the impact that this might have on the provision of high quality care, but obvious differences include the relatively small Scottish population ( 5.3 million) and the spread of people across Scotland, from urban to remote and rural, including small island health boards. However, while this could lead to variation in how services are organised and delivered, the standards of safety, effectiveness and experience should be similar within the NHS in both countries.

Despite these differences, there have been similar recent policy initiatives in England to promote high quality healthcare (and to emphasise the role of boards in this) to those already described in Scotland. These include High Care Quality for All which aimed to put quality at the heart of the NHS and the introduction of Quality Accounts in 2010 which required providers to publish annual reports about the quality of their care alongside their financial accounting.? This reflected the English National Quality Board's view that 'ultimately, it must be the board and leaders of provider organisations that take final and definitive responsibility for improvements, successful delivery, and equally failures, in the quality of care'. ${ }^{8}$ In recent months, the Francis Report examined these themes further and found that in one NHS Foundation Trust in particular there had been a disengagement from managerial and leadership responsibilities in relation to providing safe, high quality care. ${ }^{9}$ The report's recommendations, which are relevant to the wider NHS in England, include greater accountability for senior managers and leaders in protecting the interests of patients.

The role of boards in improving quality and safety of patient care is therefore recognised as important. However, there is very limited evidence about how effective boards are in undertaking this role - the only published studies are from the USA. They reported associations between the time spent by boards on quality issues and the quality of care their organisations provided. ${ }^{10.11}$ Whether or not such associations are causal is unclear. ${ }^{12}$ However, qualitative research supports the notion that if boards pay attention to quality, so will managers and, in turn, clinicians. ${ }^{13}$

It has been suggested following review of minutes from trust board meetings that while NHS trust boards in England have come a long way in the last ten years in terms of non-executive board members challenging Executive members, there is still considerable scope for improvement. ${ }^{14} \mathrm{~A}$ report covering commissioners and providers in England concluded that there is currently a gap between the best practice for boards and the reality. Examples include lack of alignment between strategic objectives and quality and safety issues, not enough time spent on quality and safety, and presentation of data that are not sufficiently robust. ${ }^{15}$

A survey of I,000 board chairs of not-for-profit hospitals in the US confirmed similar findings, stating that quality was not always a top priority, few boards had formal training in quality and that there were large variations in board activity on quality between low and high performing organisations. ${ }^{16}$ This survey was repeated in 2010 among the chairs of boards of acute trusts in the NHS in England. ${ }^{17}$ To date, there are no data to describe the role or the effectiveness of boards in improving quality in the NHS in Scotland.

Our primary aim was to find out the views of board chairs in Scotland on the level of engagement in quality management of their boards (who are responsible not only for providing but also commissioning care). Secondly, we sought to compare this with the views of chairs of boards of acute trusts in England (who are responsible for providing but not commissioning care) and to determine whether the different responsibilities of these boards influence their prioritisation of quality issues.

\section{METHODS}

The questionnaire used in the USA ${ }^{16}$ was subsequently modified for use in England and further amended for use in Scotland. Changes from the version used in England were minimal to ensure comparability of the results. The face and content validity of the Scottish version was initially tested with two executive board directors from two health boards and some minor alterations were made. The final version sought the views of the board chairs on five aspects:
A. Board training and expertise in quality
B. Quality of care as a priority
C. Influence of board and chief executive on quality of care
D. Current performance and quality of services provided
E. Ways in which boards use data on quality

Quality was defined as encompassing safety, effectiveness and patient experience (humanity). Although quality management was not explicitly defined for the respondents, we expected it to cover the oversight of quality assessment and improvement. Questions about boards 'spending time reviewing quality' referred to activities such as considering the number of adverse incidents (including mortality) and the results of clinical audits of the effectiveness of care.

In terms of the questions about training in quality, we did not make any assumptions; we accepted the generally held view that, like training and education in general, it probably 
enhances people's understanding and competence. For board expertise in quality we expected that having a clinical background (defined as being a doctor, nurse or allied health professional) would be associated with knowledge and understanding of clinical aspects of quality (safety and effectiveness), though not necessarily an understanding of other organisational aspects.

The questionnaire was sent to the chairs of the 14 territorial health boards in NHS Scotland in January 20I I.Non-responders were followed up and replacement copies of the questionnaire were provided on request. The data were analysed in an Excel spreadsheet (simple descriptive, comparative statistics) and, where applicable, the response categories previously used in the English survey were employed.

In the English study, chairs' responses were compared with independent measures of performance in their healthcare organisation. This was not possible in the Scottish survey because the small number of boards precluded quantitative estimation of associations and because of the lack of directly comparable data, such as the Care Quality Commission indicators used in England.

Data from some questions in the survey have not been included in the analyses, because either the equivalent English data were not available for comparison or there was insufficient information to make a confident interpretation.

\section{RESULTS}

\section{A. Board training and expertise in quality}

Chairs in Scotland had been members of their board for a considerable period of time (median six years), longer than in England (median four years). There was, however, little difference in the length of time as chair (about three years) (Table I). The most noticeable difference was that in Scotland there were twice as many nonexecutive directors (NEDs) as executive directors on the boards (mean I4 vs 6) whereas in England the two were similar in number. Scottish boards met less frequently than in England.

Although none of the Scottish chairs had a clinical background, most boards included at least one NED with clinical training (92\%). This contrasted with the situation in England where only $42 \%$ of boards included clinically trained NEDs. Despite this, chairs in Scotland were no more likely to perceive that their NEDs had 'very substantial expertise' in quality management. About half the Scottish boards provided formal training in quality management for their members (similar to England) although Scottish chairs were more likely to believe that additional training would be useful.
TABLE I Composition of the Board and expertise in quality management

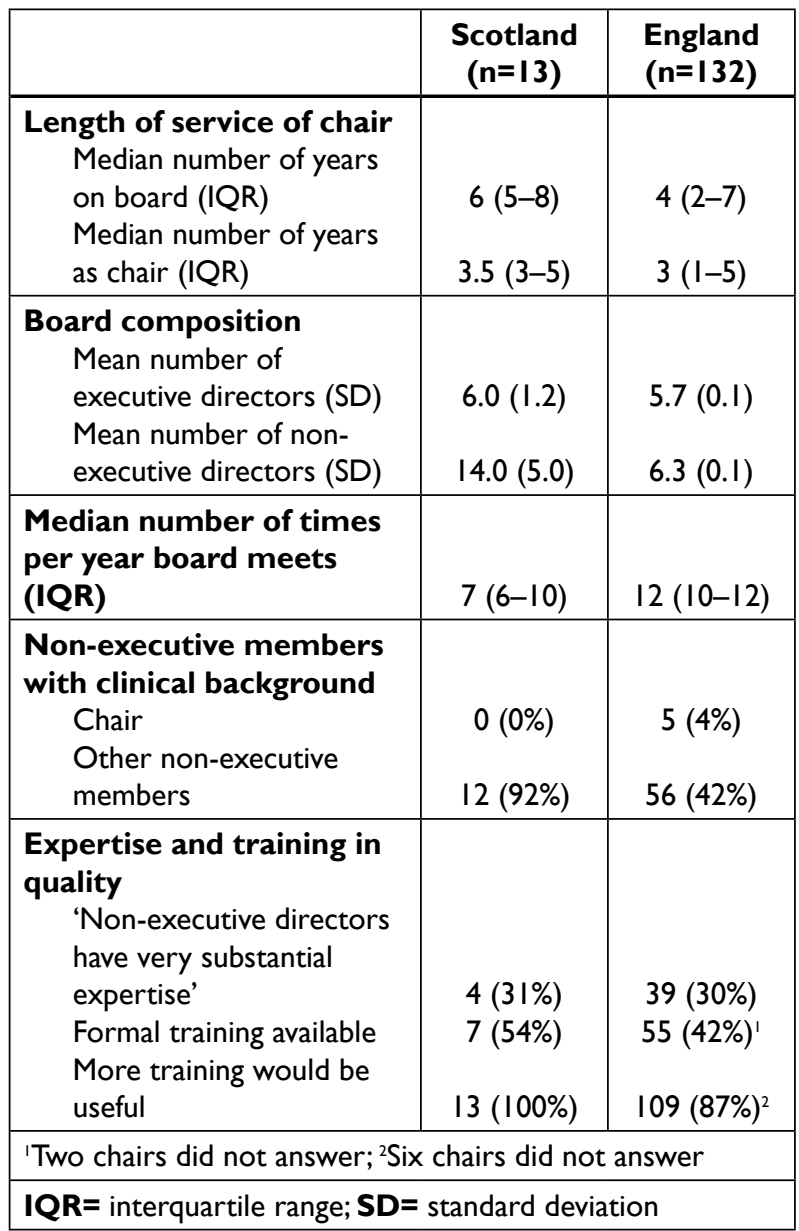

Most Scottish chairs (85\%) were familiar with the three key quality programmes in Scotland that relate to delivering safe, effective, person-centred care (the Healthcare Quality Strategy, the Better Together Programme and the SPSP).

\section{B. Quality as a priority}

In Scotland most chairs considered quality of care to be the most important aspect for them to oversee (Table 2). However, there was a sizable minority (33\%) who gave priority to organisational and financial concerns. The principal difference from England was that in Scotland the emphasis was more likely to be on clinical effectiveness ( $33 \%$ vs $10 \%$ ) than on safety (33\% vs $63 \%$ ). When considering safety, while boards in both countries were concerned about hospital-acquired infections (HAls) (100\% for both), in England medication errors were also a major issue ( $84 \%$ vs $50 \%$ ).

Almost all Scottish boards review quality at every meeting, with the majority spending more than a fifth of their time on aspects of quality (as previously defined) (Table 2 ). In comparison, only $31 \%$ reported spending as much time on financial performance. In these regards, Scottish boards were similar to their 
TABLE 2 Most important area for board oversight and board commitment to quality management (frequency and time spent in meetings and use of local targets)

\begin{tabular}{|c|c|c|}
\hline & $\begin{array}{l}\text { Scotland } \\
(n=13)\end{array}$ & $\begin{array}{l}\text { England } \\
(n=132)\end{array}$ \\
\hline $\begin{array}{l}\text { Most important area for } \\
\text { board oversight } \\
\text { Organisation and finance } \\
\text { Patient and public involvement } \\
\text { Quality of care } \\
\text { Clinical effectiveness } \\
\text { Safety } \\
\text { Patient experience }\end{array}$ & $\begin{array}{c}4(33 \%) \\
0(0 \%) \\
8(67 \%) \\
4(33 \%) \\
4(33 \%) \\
0(0 \%)\end{array}$ & $\begin{array}{c}24(18 \%) \\
7(5 \%) \\
101(77 \%) \\
13(10 \%) \\
83(63 \%) \\
5(4 \%)\end{array}$ \\
\hline $\begin{array}{l}\text { Issues reviewed at every } \\
\text { meeting } \\
\text { Quality } \\
\text { Finance }\end{array}$ & $\begin{array}{l}12(92 \%) \\
13(100 \%)\end{array}$ & $\begin{array}{l}129(98 \%) \\
123(93 \%)\end{array}$ \\
\hline $\begin{array}{l}\text { More than } 20 \% \text { of meeting } \\
\text { spent on issue } \\
\text { Quality } \\
\text { Finance }\end{array}$ & $\begin{array}{l}9(69 \%) \\
4(31 \%)\end{array}$ & $\begin{array}{c}109(83 \%) \\
50(39 \%)\end{array}$ \\
\hline $\begin{array}{l}\text { Dimensions of quality } \\
\text { reviewed at least } \\
\text { quarterly } \\
\text { Clinical effectiveness } \\
\text { Safety } \\
\quad \text { Hospital-acquired } \\
\text { infections } \\
\quad \text { Medication errors } \\
\text { Patient experience }\end{array}$ & $\begin{array}{l}12(92 \%) \\
13(100 \%) \\
6(50 \%)^{\prime} \\
11(85 \%)\end{array}$ & $\begin{array}{l}125(96 \%)^{2} \\
132(100 \%) \\
108(84 \%)^{3} \\
122(92 \%)\end{array}$ \\
\hline $\begin{array}{l}\text { Local targets in addition } \\
\text { to national targets } \\
\text { Clinical effectiveness } \\
\text { Safety } \\
\text { Hospital-acquired } \\
\text { infections } \\
\text { Medication errors } \\
\text { Patient experience }\end{array}$ & $\begin{array}{l}8(80 \%)^{3} \\
8(73 \%) \\
5(50 \%)^{3} \\
6(60 \%)^{3}\end{array}$ & $\begin{array}{l}113(86 \%)^{5} \\
128(97 \%)^{4} \\
92(70 \%)^{6} \\
118(94 \%)^{7}\end{array}$ \\
\hline $\begin{array}{l}\text { Quality dashboard/ } \\
\text { scorecard reviewed } \\
\text { regularly }\end{array}$ & $10(77 \%)$ & $129(98 \%)$ \\
\hline $\begin{array}{l}\text { Board has a quality sub- } \\
\text { committee }\end{array}$ & $10(77 \%)$ & 107 (8।\%) \\
\hline
\end{tabular}

counterparts in England. All three dimensions of quality (effectiveness, safety, experience) were considered at least quarterly in both countries. The only difference was that fewer Scottish boards considered medication errors regularly $(50 \%$ vs $84 \%)$. We did not distinguish whether any of these aspects of quality were part of local or national initiatives.

Most boards in Scotland set local targets, in addition to national ones, to improve quality and regularly reviewed a dashboard of quality indicators (77\%) (Table 2). In
TABLE 3 Principal influence on the board regarding quality and importance of quality management in chief executive's role

\begin{tabular}{|l|c|c|}
\hline & Scotland & England \\
\hline $\begin{array}{l}\text { Principal influence on the } \\
\text { board regarding quality: }\end{array}$ & $\mathbf{( n = 1 3 )}$ & $\mathbf{( n = I 1 8 )}$ \\
$\begin{array}{l}\text { Chief executive } \\
\text { Chair or other non-executive }\end{array}$ & $5(38 \%)$ & $52(44 \%)$ \\
Director & $1(8 \%)$ & $8(7 \%)$ \\
Board's quality sub-committee & $3(23 \%)$ & $6(5 \%)$ \\
Executive director & $4(30 \%)$ & $51(43 \%)$ \\
$\quad$ Medical director & $2(15 \%)$ & $20(17 \%)$ \\
Director of nursing & $2(15 \%)$ & $31(26 \%)$ \\
\hline Importance of quality & $(\mathbf{n}=13)$ & $\mathbf{( n = 1 3 2 )}$ \\
management in chief & & \\
executive's role: & & \\
$\quad$ Greater engagement in & $2(15 \%)$ & $33(25 \%)$ \\
$\quad$ quality than finance & $(\mathbf{n = 1 2 )}$ & $\mathbf{( n = 1 2 3 )}$ \\
\hline Most important area in & & \\
evaluating performance & $6(50 \%)$ & $52(42 \%)$ \\
Organisation and finance & $2(17 \%)$ & $15(12 \%)$ \\
$\quad$ Financial performance & $0(0 \%)$ & $4(3 \%)$ \\
Operations & $4(33 \%)$ & $33(27 \%)$ \\
Business strategy & $0(0 \%)$ & $0(0 \%)$ \\
Patient and public & $6(50 \%)$ & $71(58 \%)$ \\
involvement & $3(25 \%)$ & $13(11 \%)$ \\
Quality of care & $3(25 \%)$ & $50(41 \%)$ \\
Clinical effectiveness & $0(0 \%)$ & $8(7 \%)$ \\
Safety & & \\
Patient experience & & \\
\hline
\end{tabular}

England the proportion of boards setting local targets was higher across all quality dimensions, similarly a higher proportion of English boards (98\%) set local targets. Most Scottish boards also had a quality subcommittee, similar to in England.

\section{Influence of board and chief executive on quality of care}

The principal influence on quality at board level in Scotland was perceived by chairs to be equally divided between the chief executive (38\%), executive directors (30\%) and a board sub-committee on quality (23\%) (Table 3). The relevant executive directors were doctors or nurses. A similar diversity was observed in England, where less influence was perceived to come from a board sub-committee on quality $(5 \%)$ and more from the executive directors (43\%).

Despite the key contributions of the chief executive in many organisations, only two health boards (15\%) believed that the chief executive is more engaged with quality than finance (Table 3). When evaluating individual performance, quality was deemed to be the most important topic by only half the chairs, similar to the findings in England. 


\section{Current performance and quality of services provided}

Chairs felt that the quality of services their organisation provides were either the same as others or better (Table 4). No one felt their performance was worse as regards patient experience and only one chair thought this was true for staff experience. Compared with England, Scottish chairs were less likely to be self-critical: I $\%$ of English chairs thought their patients' experience was worse or much worse than others. Similarly, 19\% of English chairs thought that staff experience was worse or much worse, compared with $8 \%$ in Scotland.

TABLE 4 Chair's view of their board/trust's performance compared with others

\begin{tabular}{|l|c|c|}
\hline & $\begin{array}{c}\text { Scotland } \\
(\mathbf{n}=13)\end{array}$ & $\begin{array}{c}\text { England } \\
(\mathbf{n}=126)\end{array}$ \\
\hline Patient experience & $0(0 \%)$ & $\mathrm{I}(1 \%)$ \\
Much worse & $0(0 \%)$ & $12(10 \%)$ \\
Worse & $6(46 \%)$ & $44(35 \%)$ \\
About the same & $4(31 \%)$ & $42(33 \%)$ \\
Better & $3(23 \%)$ & $27(21 \%)$ \\
Much better & & \\
\hline Staff experience & $0(0 \%)$ & $1(1 \%)$ \\
Much worse & $1(8 \%)$ & $23(18 \%)$ \\
Worse & $7(58 \%)$ & $51(39 \%)$ \\
About the same & $2(17 \%)$ & $31(24 \%)$ \\
Better & $2(17 \%)$ & $19(15 \%)$ \\
Much better & \multicolumn{2}{|c}{} \\
\hline
\end{tabular}

\section{E. Ways in which boards use data on quality}

The majority of chairs in Scotland reported that data are used to provide feedback to staff on clinical effectiveness, patient safety and patient experience (Table 5). This was also the case in England. Fewer Scottish boards used these data further to give awards for high performance and only a minority provided financial incentives for staff, similar to the position in England.

\section{DISCUSSION}

\section{Main findings}

The oversight of quality is considered to be the highest priority for the board by most Scottish chairs. To support this, chairs reported that quality appears on almost all board meeting agendas (often taking up more than $20 \%$ of the time) and most chairs report that their boards have set local quality targets in addition to those stipulated nationally. They also report that data on quality are regularly fed back to staff although there is little use of these data as a basis for rewards (recognition or financial) for performance. Overall, chairs believe that their board compares well with others, reporting that for both patient and staff experience they perform as average or better than average. None of the chairs perceive their Board's performance as worse than
TABLE 5 Ways in which data on quality used by boards on a regular basis

\begin{tabular}{|c|c|c|}
\hline & $\begin{array}{c}\text { Scotland } \\
(n=13)\end{array}$ & $\begin{array}{l}\text { England } \\
(n=132)\end{array}$ \\
\hline $\begin{array}{l}\text { Clinical effectiveness } \\
\text { Provide feedback to clinical } \\
\text { staff } \\
\text { Awards/recognition for staff } \\
\text { for high performance } \\
\text { Financial incentives to staff for } \\
\text { high performance }\end{array}$ & $\begin{array}{l}\text { I I (92\%)' } \\
4(33 \%)^{\prime} \\
\text { I (8\%) }\end{array}$ & $\begin{array}{l}78(60 \%)^{\prime} \\
62(48 \%)^{3} \\
6(5 \%)^{2}\end{array}$ \\
\hline $\begin{array}{l}\text { Safety } \\
\text { Provide feedback to clinical staff } \\
\text { Awards/recognition for staff } \\
\text { for high performance } \\
\text { Financial incentives to staff for } \\
\text { high performance }\end{array}$ & $\begin{array}{l}12(92 \%) \\
5(38 \%) \\
1(8 \%)\end{array}$ & $\begin{array}{l}101(78 \%)^{2} \\
57(44 \%)^{2} \\
7(5 \%)^{3}\end{array}$ \\
\hline $\begin{array}{l}\text { Patient experience } \\
\text { Provide feedback to clinical staff } \\
\text { Awards/recognition for staff } \\
\text { for high performance } \\
\text { Financial incentives to staff for } \\
\text { high performance }\end{array}$ & $\begin{array}{l}9(69 \%) \\
4(31 \%) \\
I(8 \%)\end{array}$ & $\begin{array}{l}91(72 \%)^{4} \\
55(44 \%)^{5} \\
6(5 \%)^{6}\end{array}$ \\
\hline \multicolumn{3}{|c|}{$\begin{array}{l}\text { 'One chair did not respond; }{ }^{2} \text { two chairs did not respond; } \\
{ }^{3} \text { three chairs did not respond; }{ }^{4} \text { six chairs did not respond; } \\
{ }^{5} \text { seven chairs did not respond }\end{array}$} \\
\hline
\end{tabular}

average. The principal influencers of quality were either the chief executive, another executive director with a clinical background or a quality sub-committee of the board (chaired by a NED). Generally, the chair and nonexecutive directors were not seen as influential.

However, although chairs perceived that consideration of quality was their board's priority, chief executives were seen as more engaged in finance (despite quality apparently being the most important consideration for half the chairs when evaluating a CEO's performance).

Compared with England, Scottish chairs have been on their board, and in their position, for longer than their counterparts in England. Scottish Boards have a greater number of NEDs and are more likely to have a NED with a clinical background. However, Scottish Boards meet less frequently than those in England and focus less on quality, discuss it for a shorter time, review data less frequently and set fewer local targets. The priority when quality is discussed is effectiveness of care, whereas in England the priority is safety. As regards safety, most Scottish boards give greatest priority to HAls, while in England medication errors are also prioritised. Even though Scottish boards review data less frequently than in England, chairs report greater use of data to provide feedback to staff. However, data on quality are less regularly used to provide rewards for staff than in England. Scottish chairs are more optimistic about their board's performance on patient and staff experience than chairs in England. 


\section{Limitations}

There are a number of limitations to this study. First, these are self-reported views of board chairs rather than objective evidence about the management of quality in their organisations. There is probably a tendency for chairs to overestimate the extent and effectiveness of quality management, as is evident by the finding that almost all considered their board's performance was average or better than average. Second, there are only a small number of boards in Scotland so the extent of quantitative analysis is very limited. However, the high response rate means that the findings are representative of Scotland overall.

Third, although the original questionnaire used in the USA was developed and tested using rigorous methodology and further limited testing was carried out in Scotland, there may have been different interpretations of some questions (face validity). For example, chairs were asked to consider their use of 'scorecards and goals in addition to those set nationally'. It is unclear if the responses consistently distinguished national from local. This was also the case for the reported use of a 'scorecard'; a random review of board papers in Scotland suggests that these are not as widely used as reported.

Fourth, we were unable to assess the standard of the activities that were reported. For example, how good the training, scorecards or expertise were. Similarly, we could not assess respondents' understanding of terms used. Although quality was defined, other terms such as 'quality management' and 'clinical effectiveness' were not. It is possible (and even likely) that different interpretations were made.

\section{Interpretation of findings}

In many ways, the views of the chairs of Scottish boards are similar to those of their counterparts, the chairs of acute trusts in England. As in England, Scottish chairs consider the management of quality a high priority, prioritising safety and effectiveness over experience (humanity of care) despite the latter being the principal area of concern for patients and being easily open to improvement. Another similarity is the tendency in both countries for most chairs to consider the clinical services they provide as being either of average or better-than-average quality, which suggests that some chairs may be overestimating the quality of care that their organisation provides.

Although chairs report that their boards supplement national initiatives with local ones, there is less emphasis on the latter in Scotland, than appears to be the case in England. This suggests a more centralised, less devolved approach in Scotland which may reflect a wider difference in healthcare policy between the two countries. It might also reflect less need for local initiatives in Scotland, given that the entire country is similar in size to some English regions, so there is less of a separation between boards and central government.

Although Scottish boards have more NEDs than in England, and more have a clinical background, chairs are no more likely to perceive them as driving the quality agenda. Instead the leadership role is taken by the CEO, an executive director with a clinical background or a quality sub-committee. This is surprising, given that clinical safety and effectiveness tend to be prioritised over patient experience, the very aspects of quality that require clinical know-how. We might have expected NEDs in England to be more influential than those in Scotland, given the greater devolution of responsibility in England as reflected in the greater autonomy enjoyed by Foundation trusts.

Similarly, despite the difference between the two countries in terms of market forces and competition, there was no more use of incentives to encourage quality improvements in England; in both countries information on the quality of services tended to be fed back to staff with little or no use of financial inducements.

\section{Implications}

Although this was a small study, it has raised questions about what more needs to be done to ensure that boards in Scotland are appropriately engaged in quality management. Chairs themselves identified the need for more training in quality management although, as with much training, there is little rigorous evidence of its effectiveness or cost-effectiveness, reflecting the methodological difficulties of evaluation. However, given the relatively small number of board members, the cost of training would be quite modest, particularly when set against the current level of resources devoted to postbasic education and training by the NHS (about $5 \%$ of total healthcare expenditure).

Some of the optimism about the quality of their services may be because of an underestimation of the levels of quality that can be achieved. Even allowing for estimates of the amount of time devoted to quality being overestimated by Scottish chairs, there is a need for some boards to consider whether they should give quality even greater attention and whether the priorities of executive members, including the CEO, should be realigned. Scottish boards appear to be less focused on quality than those in England, though this may reflect their dual role of commissioning and providing care, while English trusts focus entirely on the latter.

In order for boards to sharpen their focus on quality, a deeper understanding is needed of what boards are actually doing; for example, what boards are discussing in the reported $20 \%$ of their meeting time spent on quality and which data they are using and how. In order for the 
situation to be improved, it will be crucial to establish what boards understand about safety, effectiveness and patient experience - both how to measure these and how to improve them. These areas should be the subject of further work.

\section{REFERENCES}

I Scot.nhs.uk. Scottish Patient Safety Programme. [Internet]. Edinburgh: NHS Scotland [cited 2012 Sept 18]. Available from: http://www. scottishpatientsafetyprogramme.scot.nhs.uk/programme

2 The Scottish Government. The NHS Scotland healthcare quality strategy [Internet]. Edinburgh: The Scottish Government; 2010 [cited 2013 June 14]. Available from: http://www.scotland.gov.uk/ Resource/Doc/3II667/0098354.pdf

3 Conway J. Getting boards on board: engaging governing boards in quality and safety. The Joint Commission Journal on Quality and Safety 2008; 34:214-20.

4 The Scottish Government. Health Board elections and alternative pilots in NHS Scotland: interim evaluation report [Internet]. Edinburgh: The Scottish Government; 20II [cited 2012 Sept 18]. Available from: http://www.scotland.gov.uk/Publications/20 I I/03/0 I I25019/0

5 Greer SL, Roland D. Devolving policy, diverging values? The values of the United Kingdom's National Health Services. London:The Nuffield Trust; 2007.

6 Connolly S, Bevan G, Mays N. Funding and performance of healthcare systems in the four countries of the UK before and after devolution. London:The Nuffield Trust; 2010.

7 Department of Health. High quality care for all: NHS next stage review. London: Department of Health; 2008.

8 National Quality Board. Quality governance in the NHS - a guide for provider boards [Internet]. London: National Quality Board; 20I I [cited 2012 Sept 18]. Available from: http://www.dh.gov.uk/prod consum_dh/groups/dh_digitalassets/documents/digitalasset/ dh_125239.pdf

\section{Acknowledgements}

We are grateful to the executive directors in Scotland who commented on the draft questionnaire and to the I 3 board chairs who participated. EB is employed by NHS Lothian who funded her to do this work.

9 Francis R. Report of the Mid Staffordshire NHS Foundation Trust public inquiry. London: The Stationery Office; 2013.

10 Vaughn T, Keopke M, Kroch E et al. Engagement of leadership in quality improvement initiatives: executive quality improvement survey results. J Patient Saf 2006; 2:2-9.

I I Jiang $\mathrm{HJ}$, Lockee $\mathrm{C}$, Bass $\mathrm{K}$ et al. Board oversight of quality: any differences in process of care and mortality? J Healthcare Management 2009; 54:15-29.

12 Baker GR, Denis J-L, Pomey M-P et al. Effective governance for quality and patient safety in Canadian healthcare organizations. Ottawa: Canadian Health Services Research Foundation; 2010.

13 Reinertsen JL. Hospital Boards and clinical quality: a practical guide. Toronto: Ontario Hospital Association; 2007.

I4 Edwards N. Boards must be braver to be better. Health Serv J 20 I I; 121:16-7.

15 Institute of Chartered Secretaries. Mapping the gap: highlighting the disconnect between governance best practice and reality in the NHS [Internet]. London: ICSA; 2011 [cited 20I2 Sept 18]. Available from: http://www.icsa.org.uk/assets/files/pdfs/NHS/ICSA\%20 mapping\%20the\%20gap\%20report.pdf

16 Jha A, Epstein A. Hospital governance and the quality of care. Health Aff 2010; 29:182-7. http://dx.doi.org/10.1377/hlthaff.2009.0297

17 Jha AK, Epstein AM. A survey of Board Chairs of English hospitals shows greater attention to quality of care than among their US counterparts. Health Aff 20 I 3; 4:677-85. http://dx.doi.org// 0.1377/ hlthaff.2012.1060 